\title{
Revision of stoneflies (insecta: plecoptera) fauna in Uzbekistan
}

\author{
Natalya Lebedeva ${ }^{1,}$, Zukhra Akhmedova ${ }^{1}$, Bakhtiyor Kholmatov ${ }^{1}$, and Rasul Jumaev ${ }^{2}$ \\ ${ }^{1}$ Institute of Zoology of the Academy of Sciences of the Republic of Uzbekistan, Tashkent, \\ Uzbekistan \\ ${ }^{2}$ Tashkent State Agrarian University, University str., 2, Tashkent province, 100140 Uzbekistan
}

\begin{abstract}
This article presents data on the study of the fauna of Plecoptera watercourses in Uzbekistan. On the basis of original collections of larvae/nymphs and adults of stoneflies and data from literary sources, a revision of the fauna of stoneflies of Uzbekistan was carried out, which currently numbers 48 species belonging to 19 genera and 7 families. Among them, endemic species were identified, first identified for Central Asia and for Uzbekistan.
\end{abstract}

\section{Introduction}

Despite the implementation of multilateral studies of the biodiversity of Uzbekistan's ecosystems, in particular, water, the available information in the literature is very scarce and insufficient to solve the environmental problems of our time, and additional scientific work is required [1]. The lack of information on aquatic organisms is especially acute, among which amphibiotic insects - stoneflies of the order Plecoptera - are considered one of the important components of indicators of the ecological state and water quality of surface sources $[1,2]$.

Hydrobiological studies in the territory of Uzbekistan were carried out mainly on large rivers and lake-river systems, while the study of water bodies of small rivers and water bodies of the republic is insignificant and remains poorly studied $[2,3]$. The fauna of the stoneflies of Uzbekistan also remains insufficiently studied, since the stoneflies were studied mainly as an integral part of the zoobenthos [3, 12].

The fauna of stoneflies of Central Asia, in particular Uzbekistan, is extremely poorly studied. In the first literary reports, mostly foreign [1,2], there are only a few scattered descriptions of the species, which make it possible to judge the presence of representatives of 5 families of this order in flowing water bodies of mainly mountainous regions of Central Asia [3].

The first list of stoneflies of Central Asia, consisting of 20 species, is given by LA Zhiltsova in 1969, indicating that 3 species (Protonemurameyeri Pict, Amphinemurastandfussi Ris, Nemouraavicularis Mort) are clearly identified erroneously and 4 are identified as Nemourasp, Leuctrasp, Capniasp, and Isogenussp [4-8]. Of the 9 represented species of the Nemouridae family, only 5 species are reliably indicated, of

\footnotetext{
* Corresponding author: natalya.lebedova@yandex.com
} 
which 3 species of the genus Amphinemura (A. crinata Kop, A maracandica McL, $A$ tragula Kimm) and 2 species of the genus Nemoura ( $N$ cinerea Retz, $N$ ornate $\mathrm{McL}$ ). The family Capniidae was especially poorly collected and studied earlier. From this family, 1 genus and 1 species are reliably indicated (Capnia turkestanica Kimmins, 1950) [6-8].

The second species, Capnianigra Pict, was clearly identified in error, as can be judged from the remark of Kimmins, who described the species Capnia turkestanica and indicated that he describes this species from the specimens identified earlier by McLachlan [1875] as Capnianigra Pict $[12,14]$.

In 1969 L.A. Zhiltsova published a description of 5 new Central Asian species: 4 from the genus Capnia ( $C$ bimaculata Zhiltz, $C$ hamifera Zhiltz, $C$ longicauda Zhiltz, $C$ prolongata Zhiltz); 1 genus and 1 species new to Central Asia - Isocapnia (I aptera Zhiltz), and Capnia species are close to the Tibetan and Himalayan species; complements the descriptions of Capnia turkestanica Kimmins, 1950 and 1 genus new to the fauna of the CIS - Eucapnopsis (E stigmatica transversa Aubert) [4].

In 1970 L.A. Zhiltsova carried out a revision of the Central Asian species of stoneflies of the genus Mesoperlina Klap from the family Perlodidae. The genus includes 5 species: $M$ ochracea, $M$ muricata, M pecirkai, $M$ capnoptera and a new species described from the Turkestan and Gissar ridges $[5,6]$.

In 1971 L.A. Zhiltsova supplements the list of Central Asian species of stoneflies of the family Nemouridae: 4 species of the genus Amphinemura - Nemoura (Amphinemura) tragula Kimm., Nemoura (Amphinemura) maracandica McL., Nemoura (Amphinemura) gritsayaeZhiltzova, sp. n., Nemoura (Amphinemura) zimmermanni Joost,; 4 species of the genus Nemoura - Nemoura (Nemoura) hamulata Zhiltzova, sp. n., Nemoura (Nemoura) alabeli Zhiltzova, sp. n., Nemoura (Nemoura) lepnevae Zhiltzova, sp. n., Nemoura (Nemoura) ornate McLachlan and 2 species of the genus Protonemura - Nemoura (Protonemura) vaillanti (Navas), Nemoura (Protonemura) tianshanica Zhiltzova, sp. n. It was reported that the early indication of the presence of Amphinemurastandfussi in the fauna of Central Asia is erroneous and gives a description of 5 species new to science: Nemoura (Amphinemura) gritsayae Zhiltzova, sp. n., Nemoura (Nemoura) hamulata Zhiltzova, sp. n., Nemoura (Nemoura) alabeli Zhiltzova, sp. n., Nemoura (Nemoura) lepnevae Zhiltzova, sp. n., and Nemoura (Protonemura) tianshanica Zhiltzova, sp. N [4-8].

A brief overview of the insect fauna of Uzbekistan $(25$ species from 9 genera and 6 families) covering the territory of the neighboring republics of Central Asia reports the identification of 52 species from 10 genera and 6 families of stoneflies, of which about $80 \%$ are endemic [8]. Noting at the same time that the fauna of stoneflies of Central Asia is very peculiar and its main features are: pronounced impoverishment, a high degree of endemism at the species level, a connection with the Central Asian fauna, and the absence of widespread Palaearctic species are noted. A number of genera and even one family, richly represented in other regions of the Palaearctic, are absent here. The impoverishment of the fauna is manifested in a general decrease in the number of species, while the percentage $(80 \%)$ of endemic species is high, only some of them go beyond Central Asia $[13,15]$.

Thus, the main purpose of this work was to revise the fauna of stoneflies in watercourses in Uzbekistan and study the modern species composition.

\section{Materials and methods}

Monitoring of the breeding sites of stoneflies, subject to varying degrees of anthropogenic impact, was carried out from May to November 2017-2019 by route surveys of flowing freshwater reservoirs of different types (rivers, sais, springs, irrigation collectors, irrigation ditches) and visual inspection of stones immersed in their water and vegetation in 5 regions of Uzbekistan: northeastern (Tashkent, Tashkent province), eastern (Namangan, Fergana 
provinces), central (Bukhara, Jizzakh, Navoi, Samarkand provinces), southern (Kashkadarya, Surkhandarya provinces) and southwestern (Republic Karakalpakstan) [12, $18]$.

The collection of larvae/nymphs of stoneflies from water bodies was carried out manually or with tweezers during visual inspection of stones and submerged vegetation near the coast and on rifts, as well as taking a sample of macrozoobenthos from the water body $[13,16]$.

The larvae/nymphs of stoneflies collected during visual inspection of stones and flooded objects were selected manually or with tweezers, immediately placed in a separate container and fixed with a $70^{\circ}$ ethanol solution, which was labeled with the date and place of collection, coordinates, and the name of the collector.

To collect macrozoobenthos in a watercourse, depending on the depth and speed of water flow, they washed off stones and other flooded objects into a hydrobiological net (ø $20 \mathrm{~cm}$ from gas) or dug up pebbles and stones with our feet in front of a net placed against the stream so that insects would fall into the net [9-11].

Thus collected in a net, the biomass was immediately carefully washed under running water and then transferred to a container with tweezers, fixing with a $70^{\circ}$ ethanol solution and providing a label indicating the date and place of collection, coordinates, and the name of the collector.

Later, in the laboratory of Entomology of the Institute of Zoology of the Academy of Sciences of the Republic of Uzbekistan, they analyzed the washings of macrozoobenthos according to systematic groups to the levels of type, class or order according to F. Mayer's method, carrying out qualitative and quantitative accounting of the collected biomass [12, 18]. Microscopic examination of insects was carried out using MEIJITECHNO stereoscopic and biological microscopes.

The collection of adults of stoneflies found on plants, stones, or other objects near water bodies and at the surface of the water was carried out manually or with tweezers. Flying insects were caught with an entomological net (ø $20 \mathrm{~cm}$ made of dense fabric or gas) by the "mowing" method over vegetation (100 sweeps of $1 \mathrm{~m}$ in one direction and back). Then the collected insects were placed in a separate container, fixed with a $70^{\circ}$ ethanol solution, or, having killed, on a cotton mattress. Samples were labeled accordingly, indicating the date and place of collection, coordinates, and the name of the collector.

The identification of stoneflies was carried out mainly according to the larval stages of development (2493 larvae/nymphs, 375 adults) using the corresponding identification tables $[8-11,17]$.

The collected material is kept in the funds of the Entomological collection of the Institute of Zoology of the Academy of Sciences of the Republic of Uzbekistan.

\section{Results and discussion}

The monitoring of the places of breeding trees, carried out by us in the watercourses of 5 regions of Uzbekistan (northeastern, eastern, central, southern and southwestern regions), made it possible to obtain data on their uneven, sometimes even local, settlement across the territory of the republic. The survey covered 129 watercourses in 32 regions of the republic (Tashkent city, 9 provinces and the Republic of Karakalpakstan) and collected 663 samples of macrozoobenthos.

The index of occurrence of stoneflies in the republic in samples of zoobenthos was $37.1 \%$, in regions $-28.1 \%$. Most often, stoneflies were found in the mountain-foothill watercourses of the northeastern and southern $(33.3 \%)$, central $(22.2 \%)$ and eastern $(11.1 \%)$ regions. No freckles were found in samples from the southwestern region (steppe, desert) of the republic (Republic of Karakalpakstan). Based on original collections of larvae/nymphs 
of stoneflies in watercourses of the republic and adults around them $[17,18]$, as well as data from literary sources, we revised the fauna of the stoneflies of Uzbekistan, taking into account the synonymous names, which made it possible to clarify the composition of the fauna of the stoneflies of Uzbekistan (Table 1).

Table 1. Species composition of stoneflies (Plecoptera) in water sources in Uzbekistan.

\begin{tabular}{|c|c|c|}
\hline Family & Genus & Type \\
\hline \multicolumn{3}{|c|}{ Systellognatha Enderlein Group, 1969 : Zwick, 2000} \\
\hline \multirow[t]{13}{*}{$\begin{array}{c}\text { Perlodidae } \\
\text { Klapálek, } 1912 \\
\end{array}$} & Isoperla Banks, 1906 & $\begin{array}{c}\text { Isoperla difformis Klapálek, } 1909 \\
\text { (=Chloroperla difformis Klapálek, 1909) }\end{array}$ \\
\hline & & Isoperlasp. \\
\hline & Mesoperlina Klapálek, 1921 & $\begin{array}{c}\text { Mesoperlina capnoptera (McLachlan, } \\
\text { 1886) (=Chloroperla capnoptera } \\
\text { McLachlan, } 1886 \text { - ceм. Chloroperlidae)* }\end{array}$ \\
\hline & & Mesoperlinaochracea Klapálek, 1921 \\
\hline & & Mesoperlinapecirkai Klapálek, 1921* \\
\hline & & Mesoperlinasp. \\
\hline & Arcynopteryx Klapálek, 1904 & Arcynopteryx compacta McLachlan, 1892 \\
\hline & Diura Billberg, 1820 & Diura knowltoni Frison, $1937 * *, * * *$ \\
\hline & & Diura sp. \\
\hline & Filchneria Klapálek, 1908 & $\begin{array}{c}\text { Filchneria mesasiatica Zhiltzova, 1971*, } \\
* * *\end{array}$ \\
\hline & & Filchneriamongolica (Klapálek, 1901) \\
\hline & & $\begin{array}{l}\text { Filchneria olgae McLachlan, } 1875 \\
\text { (=Dictyopteryx olgaeMcLachlan, 1875; } \\
\text { Skobeleva olgae (McLachlan, 1875)* }\end{array}$ \\
\hline & & Filchneria sp. \\
\hline \multirow[t]{5}{*}{$\begin{array}{c}\text { Perlidae } \\
\text { Latreille, } 1802\end{array}$} & $\begin{array}{c}\text { Agnetina Klapálek, } 1907 \text { (=Perla } \\
\text { Geoffroy, 1761) }\end{array}$ & $\begin{array}{c}\text { Agnetina cocandica } \text { (McLachlan, 1875) } \\
\text { (=Kamimuriacostulata Navás, 1923; } \\
\text { Perlacocandica McLachlan, } \\
\text { 1875;Phasganophoraundata } \\
\text { Klapálek,1921) }\end{array}$ \\
\hline & & $\begin{array}{c}\text { Agnetina immersa }(\text { McLachlan, } 1875) \\
(=\text { Perlaimmersa McLachlan, 1875)* }\end{array}$ \\
\hline & & $\begin{array}{c}\text { Agnetina pedata }(\text { Koponen, 1949) } \\
\text { (=Phasganophora pedata Koponen, 1949)* }\end{array}$ \\
\hline & & Agnetina sp. (=Phasganophora sp.). \\
\hline & $\begin{array}{l}\text { Dinocras Klapálek, } 1907: \\
\quad \text { Claassen, } 1940\end{array}$ & $\begin{array}{l}\text { Dinocras cephalotes (Curtis, 1827) } \\
\text { (=Perlabaetica } \text { Rambur, 1842; } \\
\text { Perlacephalotes Curtis, } 1827)\end{array}$ \\
\hline \multirow[t]{4}{*}{\begin{tabular}{|c|} 
Chloroperlidae \\
Okamoto, $1912:$ \\
Illies, 1966 \\
\end{tabular}} & $\begin{array}{l}\text { Chloroperla Newman, } 1836 \\
\text { (=Isopteryx Pictet, 1841) }\end{array}$ & $\begin{array}{l}\text { Chloroperlatripunctata (Scopoli, 1763) } \\
\text { (=Isopteryx tripunctata Scopoli, 1763) }\end{array}$ \\
\hline & Siphonoperla Zwick, 1967 & $\begin{array}{c}\text { Siphonoperla montana Pictet, F.J., } 1841: \\
\text { Zwick, P. } 1972 \text { (=Perla (Isopteryx) } \\
\text { montana Pictet, F.J., 1841; Chloroperla } \\
\text { montana Pictet, F.J., 1841) }\end{array}$ \\
\hline & Xanthoperla Zwick, 1967 & $\begin{array}{c}\text { Xanthoperla curta McLachlan, } 1875 \\
(=\text { Chloroperla curta } \text { McLachlan, 1875)* }\end{array}$ \\
\hline & & Xanthoperla sp. \\
\hline \multicolumn{3}{|c|}{ Euholognatha Zwick Group, 1973 : Zwick, 1969} \\
\hline $\begin{array}{c}\text { Taeniopterygidae } \\
\text { Klapálek, } 1905\end{array}$ & Mesyatsia Ricker et Ross, 1975 & $\begin{array}{c}\text { Mesyatsiatianshanica (Zhiltzova, 1972) } \\
\text { (=Rhabdiopterixtianshanica Zhiltzova, } \\
1972)^{*}\end{array}$ \\
\hline
\end{tabular}




\begin{tabular}{|c|c|c|}
\hline $\begin{array}{l}\text { Nemouridae } \\
\text { Newman, } 1853\end{array}$ & Amphinemura Ris, 1902 & $\begin{array}{l}\text { Amphinemura crenata Koponen, } 1949 \\
\text { (=Nemoura crenata Koponen, 1949)* }\end{array}$ \\
\hline & & $\begin{array}{c}\text { Amphinemura maracandica (McLachlan, } \\
\text { 1875) (=Taeniopteryxmaracandica } \\
\text { McLachlan, 1875; Nemoura maracandica } \\
\text { McLachlan, 1875)* }\end{array}$ \\
\hline & & Amphinemura mirabilis (Martynov, 1928) \\
\hline & & $\begin{array}{c}\text { Amphinemura mirabilis turkestanica } \\
\text { Zhiltzova, 1978* }\end{array}$ \\
\hline & & Amphinemurasp. (sulcicollis Stephens) \\
\hline & & Amphinemura sulcicollis (Stephens, 1836) \\
\hline & & Amphinemura trialetica Zhiltzova, $1957^{* * *}$ \\
\hline & & Amphinemura zimmermanni Joost, 1970* \\
\hline & $\begin{array}{r}\text { Mesonemoura Baumann, } 1975 \\
(1971 \text { - larvae, } 1973 \text { - imago) }\end{array}$ & $\begin{array}{c}\text { Mesonemoura tianshanica (Zhiltzova, } \\
\text { 1971) (=Nemoura tianshanica Zhiltzova, } \\
\text { 1971; Protonemura tianshanica Zhiltzova, } \\
\text { 1971)* }\end{array}$ \\
\hline & & Mesonemoura vaillanti (Navás, 1922)*** \\
\hline & & Mesonemourasp. \\
\hline & Illiesonemoura Baumann, 1975 & $\begin{array}{c}\text { Illiesonemouraornata }(\text { McLachlan, } 1875) \\
(=\text { Nemoura ornata } \text { McLachlan, } 1875)^{*}\end{array}$ \\
\hline & Nemoura Latreille, 1796 & $\begin{array}{c}\text { Nemoura cinerea }(\text { Retzius, } 1783) \\
\text { (=Nemoura variegate Olivier, } 1811 ; \\
\text { Perlacinerea } \text { Retzius, } 1783)\end{array}$ \\
\hline & & Nemoura flexuosa Aubert, 1949 \\
\hline & & Nemoura lepnevae Zhiltzova, 1971* \\
\hline \multirow[t]{9}{*}{$\begin{array}{c}\text { Capniidae } \\
\text { Banks, } 1900: \\
\text { Klapálek, } 1905\end{array}$} & Capnia Pictet, 1841 & $\begin{array}{c}\text { Capnia nigra }(\text { Pictet, F.J., 1833) }(=\underline{\text { apicalis }} \\
\text { Navás, } 1930 ; \text { conica Klapálek, } 1909 ; \\
\text { maynari Navás, 1917; Perlanigra Pictet, } \\
\text { F.J., 1833) }\end{array}$ \\
\hline & & Capnia prolongata Zhiltzova, 1969* \\
\hline & & CapniaturkestanicaKimmins, 1950* \\
\hline & & Capnia sp. \\
\hline & Eucapnopsis Okamoto, 1922 & Eucapnopsissp. (stigmaticaAubert?) \\
\hline & & EucapnosisstigmaticaOkamoto, 1922 \\
\hline & & $\begin{array}{c}\text { EucapnosisstigmaticatransversaAubert, } \\
1959\end{array}$ \\
\hline & & Eucapnosissp. \\
\hline & Mesocapnia Raušer, 1968 & $\begin{array}{c}\text { Mesocapnia altaica (Zapekina-Dulkeit, } \\
\text { 1955) (=Capnia altaica Zapekina-Dulkeit, } \\
1955^{*}, * * *\end{array}$ \\
\hline $\begin{array}{c}\text { Leuctridae } \\
\text { Klapálek, } 1905\end{array}$ & Leuctra Stephens, 1835 & Leuctradigitata Kempny, 1899 \\
\hline Total: family -7 & Genus - 19 & Types - 48 \\
\hline
\end{tabular}

Note: * - endemics of the mountains of Central Asia and Kazakhstan, ** - identified for the first time for Central Asia, ***- identified for the first time for Uzbekistan.

From the data in the table it can be seen that the fauna of stoneflies (Plecoptera) of Uzbekistan includes 48 species from 19 genera and 7 families, of which 2 species are established before the subspecies and 9 - before the genus.

The Systellognatha group is represented by 22 species from 10 genera and 3 families: Perlodidae - 13 species from 5 genera, Perlidae - 5 species from 2 genera, and Chloroperlidae - 4 species from 3 genera. Of these, 7 species are endemics of the 
mountains of Central Asia and Kazakhstan, 1 species was detected for the first time in Central Asia and 2 species - for Uzbekistan.

More than half of the fauna of the Systellognatha group consists of species of the Perlodidae family (13 species or $59.1 \%$ ) belonging to 5 genera: Mesoperlina and Filchneria - 4 species each, Diura and Isoperla - 2 species each, Arcynopteryx - 1 species, then species of the Perlidae family ( 5 species or $22.7 \%$ ) belonging to 2 genera: Agnetina - 4 species, Dinocras - 1 species and the family Chloroperlidae (4 species or $18.2 \%$ ) - 3 genera: Xanthoperla - 2 species, Chloroperla and Siphonoperla - 1 species each.

Of the modern collections, the following are widespread and numerous: Mesoperlina pecirkai Klapálek, 1921 (northeastern, eastern and southern regions) and Diura knowltoni Frison, 1937 (northeastern, central and southern regions), less widely - Xanthoperla curta McLachlan, 1875 (north - eastern and central regions) and locally: Mesoperlina ochracea Klapálek, 1921 (eastern region), Filchneria mesasiatica Zhiltzova, 1971 and Agnetina immersa (McLachlan, 1875) (northeastern region).

The Eucholognatha group is represented by 26 species from 9 genera of 4 families: Taeniopterygidae - 1 species from 1 genus, Nemouridae - 15 species from 4 genera, Capniidae - 9 species from 3 genera, Leuctridae - 1 species from 1 genus. Of these, 11 species are endemic to the mountains of Central Asia and Kazakhstan, 3 species have been identified for the first time in Uzbekistan.

More than half of the fauna of the Eucholognatha group are species of the Nemouridae family (15 species or 57.7\%) belonging to 4 genera: Amphinemura - 8 species, Nemoura and Mesonemoura - 3 species each and Illiesonemoura - 1 species, then species of the Capniidae family (9 species or 34, 6\%) belonging to 3 genera: Capnia and Eucapnosis - 4 species each and Mesocapnia - 1 species and then 2 families (1 species each or 3.8\%): Taeniopterugidae: genus Mesyatsia - 1 species and Leuctridae: genus Leuctra - 1 view.

Among modern collections, the following are widespread and numerous: Amphinemura trialetica Zhiltzova, 1957, Mesonemoura tianshanica (Zhiltzova, 1971) and Mesonemoura vaillanti (Navás, 1922) (northeastern, eastern, and southern regions) and locally: Amphinemuraan mirabilis turkestova and Mesocapnia altaica (Zapekina-Dulkeit, 1955) (northeastern region).

\section{Conclusions}

Stoneflies monitoring carried out in 129 watercourses of 5 regions (32 districts) of the republic: northeastern (Tashkent, Tashkent province), eastern (Namangan, Fergana provinces), central (Bukhara, Jizzakh, Navoi, Samarkand provinces), southern (Kashkadarya, Surkhandarya provinces) and southwestern (Republic of Karakalpakstan), made it possible to obtain data on their uneven, sometimes even local, settlement.

The index of occurrence of stoneflies in the republic in samples of macrozoobenthos was $37.1 \%$, in regions $-28.1 \%$. Most often, stoneflies were found in the mountain-foothill watercourses of the northeastern and southern $(33.3 \%)$, central $(22.2 \%)$ and eastern $(11.1 \%)$ regions. No freckles were found in samples from the southwestern region (steppe, desert) of the republic (Republic of Karakalpakstan).

After analyzing the literature data and own collections, the fauna of Plecoptera in Uzbekistan began to total 48 species from 19 genera and 7 families, of which 2 species were established to subspecies and 9 to genus, 18 species of stoneflies are endemics of the mountains of Central Asia and Kazakhstan, 1 species was first identified for the fauna of Central Asia (Diura knowltoni Frison, 1937) and 5 species - for Uzbekistan (Diura knowltoni Frison, 1937; Filchneria mesasiatica Zhiltzova, 1971; Amphinemura trialetica Zhiltzova, 1957; Mesonemoura vaillanti, 1922; Navásnia altaica (Zapekina-Dulkeit, 1955) Species superiority ( $54.2 \%$ of the total number of species) is shifted towards the group of 
phyto- and detritivores - Eucholognatha, instead of $45.8 \%$ of the group of predators Systellognatha.

The revealed species composition of the order Plecoptera of Uzbekistan cannot be considered complete yet. This can be judged by comparing the species composition of the Plecoptera fauna of the countries of Central Asia adjacent to Uzbekistan (Kyrgyzstan, Tajikistan, Turkmenistan) and Kazakhstan. It can be assumed that further studies (new piedmont-mountain streams, collections in the autumn-winter and early spring periods, molecular genetic studies) will be able not only to clarify the species composition, but to replenish the list of species given in this message and expand the understanding of the biology of the vesnyanokpredgorno -mountain watercourses of Uzbekistan.

This work was carried out with the financial support of the grant of the Academy of Sciences of the Republic of Uzbekistan No. VA-FA-F5-011 "Orthopteroid insects (Insecta: Orthopteroidea) of Uzbekistan" (2017-2020).

\section{References}

1. R. Alimzhanov, Invertebrates, 127-128 (1996)

2. A. Brodskiy, Zoology, 15(1), 52-72 (1995)

3. S. G. Jewett, In Aquatic Insects of California, 155-181 (2021)

4. L. Zhiltsova, Entomol. review, 48(3), 593-611 (1969) (in Russian)

5. L. Zhiltsova, Entomol. review, 49(3), 578-591 (1970) (in Russian)

6. L. Zhiltsova, Entomol. review, 50(2), 347-365 (1971) (in Russian)

7. L. Zhiltsova, Insects of Uzbekistan, 28-33 (1993) (in Russian)

8. L. Zhiltsova, Plecoptera, 364-399 (1997) (in Russian)

9. N. Lebedeva, D. Golovtsov, Zoology of Uzbekistan, 38-41 (2020)

10. N. Lebedeva, B. Kholmatov, Bulletin of Khorezm Academy of Mamun, 15-17 (2019)

11. N. Lebedeva, B. Kholmatov, Zoology of Uzbekistan, 149-151 (2019)

12. Z. Mustafaeva, U. Mirzaev, B. Kamilov, Methods of hydrobiological monitoring of water bodies in Uzbekistan, 102 (Navruz press, Tashkent, 2017)

13. Z. T. Chen, Y. Z. Du, International journal of biological macromolecules, 111, 70-76 (2018)

14. L. Sibirtseva, Biology and regional medicine, 417-123 (1961)

15. R. E. DeWalt, G. D. Ower, Insects, 10(4), 99 (2019)

16. L. Sibirtseva, E. Kiseleva, M. Abdullaev, Zoology, 97-117 (1961)

17. V. Teslenko, L. Zhiltsova, Dalnauka: Russian Academy of Sciences, 382 (2009)

18. B. Murodov, J. Yakhyoyev, Education and science in Russia and abroad, 32-36 (2017) 